\title{
Interstate Economic Cooperation in Eurasia: Actual Options of Development (International Legal Aspect)
}

\section{$\Omega$ 目 Maria Shilina}

Postgraduate Student, Department of International Public and Private Law, Law Faculty, National Research University Higher School of Economics, address: 20 Myasnitskaya Str., Moscow 101000, Russia. E-mail: mary.shilina@gmail.com

\begin{abstract}
国国 Abstract
World economic power is becoming increasingly dispersed, a process accompanied by a greater role played by various international economic associations of states in regulating international economic relations. The article devoted to the fragmentation of international law demonstrates this kind of law can be grouped according to uncoordinated regulatory entities and proposes a solution to this issue. The factors in this fragmentation are analyzed through the prism of current processes in Eurasian regional economic integration. The approaches to coordinating the laws of regional economic associations with the regulations of the WTO are also reviewed. The new formats of regional intergovernmental economic cooperation in Eurasia, such as the Eurasian Economic Union (EEU) and the Silk Road Economic Belt (SREB) are analyzed. The EEU and the SREB are presently the main drivers of the transformation of Eurasia into a zone of joint development. These projects share a common goal and can harmoniously complement each other, and their potential linkage makes possible the formation of a common economic space on the Eurasian continent. The Joint Statement on Cooperation on the Construction of Joint Eurasian Economic Union and Silk Road Projects (signed by Presidents Putin and Li Xin on May 8, 2015) raises some serious issues. The main one concerns the comparison and further development of the EEU and the SREB and possible ways to have them complement each other in practice. At the Astana Club in 2015 three potential options of co-existence of the projects were considered: bilateral connection (meaning that EEU countries would be free to decide on participation in SREB), linkage within an EEU-China format, and linkage within the Shanghai Cooperation Organization (the SCO). In this paper the author attempts to identify effective solutions to the problems surrounding this process. The conclusion is effective development of the new integration projects of Russia and China on the basis of the SCO is optimal. A mechanism for international legal regulation of economic cooperation entailing a gradual economic convergence of Eurasia is proposed.
\end{abstract}

\section{0-4目 Keywords}

international law, international economic law, fragmentation of law, the Eurasian Economic Union, the Silk Road Economic Belt, the Shanghai Cooperation Organization, regional economic integration.

Citation: Shilina M.G. (2017) Interstate Economic Cooperation in Eurasia: Actual Options of Development (International Legal Aspect). Pravo. Zhurnal Vysshey shkoly ekonomiki, no 1, pp. 178-186 (in English) 


\section{Introduction. Fragmentation of International Economic Law in Eurasia}

Economic and political transformation of Eurasia ${ }^{1}$ is a key trend in the global geo-economic processes of the first half of the 21 st century ${ }^{2}$. Effective co-existence and functioning of the mechanisms of global economic organizations and regional associations of states in Eurasia (within the currently spreading processes of globalization and regionalization of economic relations) depends primarily on a harmonious relationship between them within the framework of international law (IL) and erected on the basis of $\mathrm{IL}^{3}$.

International economic relations in Eurasia are currently regulated by IL on several levels. The global level consists of multilateral international treaties within the framework of global economic organizations such as the World Trade Organization (WTO), while the regional level is based on international agreements within regional economic organizations (REO) and associations of states, whose authority extends to questions of state interactions in the field of economics. There are also newer formats for economic cooperation, such as the Chinese Silk Road Economic Belt, within which there is no established mechanism for international legal regulation of economic cooperation between states. Thus modern international economic relations between states in different macro-regions of Eurasia are being elaborated in a variety of formats and settled on several different levels. Analysis of this process holds considerable theoretical and practical interest.

The universal level of legal regulation of international economic relations based on the General Agreement on Tariffs and Trade (GATT) provides for, inter alia, member states of the WTO to grant each other most favored nation treatment and holds between most countries on the Eurasian continent.

At the same time the interaction between Eurasian countries at the regional level ${ }^{4}$ (partly due to the global economic crisis and the growing use of economic sanctions ${ }^{5}$ ) is increasing. In many Eurasian regional associations of states there are proper legal documents covering regulation of economic relations and the corresponding institutional structures. In this fashion REO create an autonomous international economic law, which may be contrary to WTO law and lead to disintegration of the international economic order, that is, to the fragmentation of international economic law, and to economic and legal divergence among legal systems around the world ${ }^{6}$. But at the same time the establishment of regional systems of law "would be an effective step towards a global legal space"7.

The academic community is actively discussing this fragmentation, which is often regarded as the separation of IL into separate magnetic fields of self-sufficient international legal regimes through its distribution to new areas of relations, as well as by its creation of a large number

${ }^{1}$ In this article Eurasia is understood as a geographical concept: the largest continent; the combined landmass of Europe and Asia.

2 Bordachjov T.V. Novoe evraziistvo // Rossiia v global'noi politike, 2015. N 5. Available at: http://www. globalaffairs.ru/number/Novoe-evraziistvo-17754 (accessed: 10.09.2016)

3 Smbatjan A.S. WTO i regional'nye integratsionnye ob"edineniia: so otnoshenie "pravovykh sil" v uregulirovanii torgovykh sporov. // Rossiiskii vneshnii ekonomicheskii vestnik, 2011.N 8.

4 Lomakin V.K. Mirovaia ekonomika. Moscow, 2007.

5 Slaughter A.M. A New World Order. Princeton, 2004.

${ }^{6}$ Cleaver T. Understanding the World Economy, N.Y., 2007. P. 121.

7 Gusejnov O.R. Mezhdunarodnaia ekonomicheskaia integratsiia v sfere mezhdunarodnogo prava // Evraziiskii juridicheskii zhurnal, 2015. No. 1. Available at: http://www.eurasialaw.ru/index.php?option=com_conten t\&view=article\&id=7080:2015-02-26-09-22-04\&catid=109:2010-06-17-09-48-32 (accessed: 10.09.2016) 
of institutions of governance ${ }^{8}$. Professor G. Hafner ${ }^{9}$ has noted that IL is heterogeneous and that it includes universal, regional and bilateral systems, as well as subsystems with different levels of legal integration. Hafner identifies two factors that contribute to fragmentation: the increasing number of international legal rules and increasing political fragmentation combined with increasing regional and global interdependence, particularly in the sphere of economics. According to J. Pauwelyn ${ }^{10}$, the conciliatory nature of IL leads to the formation of the same number of legal regimes. Other authors also believe that the problem of fragmentation is not in "erosion" 11 and reductions in the number of legal norms, but rather in the expansion of the international legal system. They refer to this phenomenon as the "proliferation" of IL".

Thus, the problem is that IL separates into uncoordinated regulatory entities. In most cases IL does not have mechanisms for coordination. This situation gives some authors reason to doubt whether IL qualifies as a legitimate form of rule of law $^{13}$. We agree with the view of Professor A. Abdullin, who writes that the international legal order is relatively centralized in a way similar to domestic law and order. The difference lies not in the nature but in the degree: in the domestic order there are more centralized regulations (related to the entire state) than decentralized ones (related to regional or municipal levels); the reverse situation is typical for $\mathrm{IL}^{14}$. In any case, IL will be contained within a certain system.

It is also essential that international economic law (whether regional or global) be governed by certain legal principles. Dr. A. Platsas ${ }^{15}$ considers some of the leading principles of general IL which govern or tend to govern international economic law: the Principle of Fidelity ${ }^{16}$; the Principle of Conferred Powers ${ }^{17}$; the Principle of Subsidiarity ${ }^{18}$; the Principle of Proportionali$\mathrm{ty}^{19}$; and the Principle of Conditionality ${ }^{20}$. These principles support the idea convergence of law.

${ }^{8}$ Davletgil'deev R.S. K voprosu o podkhodakh $\mathrm{k}$ fragmentatsii mezhdunarodnogo prava // Rossiiskii juridicheskii zhurnal, 2013. No. 3. Available at: http://base.garant.ru/57741390/ (accessed: 10.09.2016)

9 Hafner G. Riski fragmentatsii mezhdunarodnogo prava // Ezhegodnik. T. II. 2000.

${ }^{10}$ Pauwelyn J. Bridging Fragmentation and Unity: International Law as a Universe of Inter-Connected Islands // Michigan Journal of International Law, 2004. No 25.

11 Plotnikov A.V. Evolutsiia doktrinal'nykh podhodov k ponimaniju i otsenke fragmentatsii mezhdunarodnogo prava // Rossiiskii iuridicheskii zhurnal, 2013. No 3. P. 15-19.

12 Drezner D. Regime Proliferation and the Tragedy of the Global Institutional Commons, 2009. Available at: http://fletcher.tufts.edu/ /media/Fletcher/Microsites/Fila/PDFs/FILADiscussionPaperNo0109.pdf (accessed: 10.09.2016)

13 Leben C. The Advancement of International Law. Oxford, 2010. P. 339.

${ }_{14}$ Abdullin A.I. Fragmentatsiia mezhdunarodnogo prava: problemy i perspektivy // Aktual'nye problemy sovremennogo mezhdunarodnogo prava: materialy XII ezhegodnoi mezhd. nauchno-praktich. Konferentsiia pamiati prof. I.P. Blishhenko 2015. Moscow, 2015.

15 Platsas A. The Idea of Legal Convergence and Electronic Law // Values and Freedoms in Modern Information Law \& Ethics. 2012, P. 679-688.

16 This principle requires states to do more than merely refrain from breaching their international law obligations. See: Chalmers D. European Union Law, 2006. P. 193.

As a result all the parts of their legal systems "at each level and unit of government must act to ensure the proper functioning of the system of governance as a whole". See: Halberstam D. The Political Morality of Federal Systems. Virginia Law Review, Vol. 90. 2004. P. 90.

17 According to this principle, by extension, the EU and NAFTA can act only in areas which are assigned to them by the relevant treaties.

${ }_{18}$ This principle suggests that an international economic law organization is to intervene in achieving certain objectives only if the state cannot achieve these objectives at the state level.

${ }^{19}$ In the case of European economic law: all EU acts must be suitable to pursue their legitimate aims, necessary to do so and the acts must not have an excessive effect on the affected party.

${ }^{20}$ This enables an international organization to push for its agenda in various legal systems. The principle presupposes an assessor (an international organization with economic goals) and an assessed (the state which seeks to 
This theory of IL divides the causes of fragmentation of IL (including international economic law) into regulatory and institutional factors. Thus, P. Dupuy points out that there are regulations related to the trend towards autonomy of the special legal modes, as well as organic (institutional) factors, which stem from the increasing number of methods and procedures for governance to ensure the implementation of $\operatorname{law}^{21}$.

The factors in fragmentation were also considered by the UN Commission on IL in the report of a study group of the International Law Commission called "Fragmentation of International Law: Difficulties Arising from the Diversification and Expansion of International Law"22. The paper includes such sections as: fragmentation as a phenomenon; conflicts between special law and general law; and conflicts between successive norms. It also highlights relations of importance, such Article 103 of the Charter of the United Nations, and the concepts of jus cogens and obligations erga omnes as conflict rules. The report solves some basic issues, but it does not address modern factors in fragmentation.

Thus, as we see, fragmentation and the existence of several levels of regulation of interstate economic relations in Eurasia require a search for modern approaches to ensure that those relations function effectively.

\section{The Correspondence between WTO Law and the Laws of REO}

There has been substantial analysis of the impact of regional economic integration on fragmentation of international economic law due to the regulatory and institutional factors in fragmentation of IL. The question of the correspondence between WTO law and the laws of REO is especially important in considering the current Eurasian regional economic integration processes.

In the GATT / WTO system the issue of regional economic integration is generally resolved through established criteria of compliance of REO with GATT / WTO rules. The WTO has certain powers of oversight in the establishment and functioning of free trade areas and other forms of regional economic integration (Art. XXIV of GATT and Art. V of the General Agreement on Trade in Services [GATS]).

In the theory of IL there are two approaches to analyzing the relationship between WTO treaties and regional integration agreements: the monistic and the dualistic. According to the monistic approach, the WTO provides its members with the right to create regional integration associations, but only to the extent to which they comply with WTO law (thus, the WTO maintains priority over the regional associations). According to the dualistic approach, the WTO and the regional associations are independent of each other; their relationship is horizontal in nature (characterized, on the one hand, as cooperation and complementarity, and on the other as competition). We agree with A. Smbatjan, who supports the dualistic approach and shows that the system of agreements of the WTO and the agreements signed within the framework

derive economic benefit from membership to the international organization which assesses the state's compliance). In practice, the principle calls for the imposition of transparent legal rules and economic conditions to a state in return for a loan or resources as a whole (for example, from the International Monetary Fund [IMF]).

${ }^{21}$ Dupuy P. A Doctrinal Debate in the Globalization Era: On the "Fragmentation" of International Law // European Journal of Legal Studies, 2007. Vol 1. P. 25-41. // Available at: http://www.ejls.eu/1/4UK.pdf (accessed: 10.09.2016)

${ }^{22}$ Report of the Study Group of the International Law Commission «Fragmentation of International Law: Difficulties arising from the Diversification and Expansion of International Law» // A/57/10. 2006. Par. 502-504. 
of regional integration associations have the same legal force ${ }^{23}$. According to N. Lavranos, the dualistic approach also seems to be correct because there is no established priority of WTO mechanisms for settling disputes over the analogous dispute resolution procedures within the regional integration associations. In practice there is no formal hierarchy ${ }^{24}$. At the same time, the framework of agreements of regional economic integration is closely associated with WTO rules because the WTO has exercised control over most areas in the international trade of goods, services, and intellectual property.

In contemporary international law there are mechanisms that, to some extent, eliminate regulatory factors in the fragmentation of international economic law. First, the recognition of WTO law as a lex generalis in relation to REO law under the application of the general legal principle of lex specialis derogat legi generali. Second, the rule of systemic integration (Art. 31 Vienna Convention on the Law of Treaties), according to which the interpretation of contracts must take into account "any relevant rules of international law applicable in the relations between the parties"25.

At present the institutional fragmentation factor is exacerbated-by an increasing risk of competition over the extent of authority belonging to various institutions. In particular, there is conflict of jurisdiction between the judicial institutions of the WTO and judicial institutions of the REO. In the theory of IL there are some approaches that may eliminate this factor. For example, according to the approach of J. Pauwelyn, in order to avoid duplicating procedures regional integration agreements (RIAs) should include a 'forum exclusion clause': if the dispute is submitted to the WTO or to a regional judicial body, the same question may not be reconsidered by the other judicial institution ${ }^{26}$.

Thus, the operation of the REO does not undermine the integrity of the international economic order. IL and the theory of IL have certain mechanisms to eliminate regulatory and institutional factors of fragmentation. At the same time due to the process of deepening integration, there is still a need to improve these mechanisms.

\section{Eurasia: Realities and Prospects}

Within the macro-regions of Eurasia interstate economic cooperation is carried out through a network of varying mechanisms ${ }^{27}$. In Europe, these structures are characterized by a deep integration process, while in Asia and the post-Soviet region there are a number of overlapping agreements with more limited aims. The peculiarity of the Asian regional arrangements ${ }^{28}$ is their diversity, informal structure, and more flexible membership; they perform mainly advisory functions and develop specific projects, rather than impose common standards. In contrast to this polycentric network, the post-Soviet regional projects ${ }^{29}$ are centered on Russia.

${ }^{23}$ Smbatjan A.S. Op. cit.

${ }^{24}$ Lavranos N. The Brazilian Tyres Case: Trade Supersedes Health. Trade, Law and Development. 2009. Vol. 1. No 2. P. 191-230.

25 Vienna Convention on the Law of Treaties, signed at Vienna May 23, 1969. In effect from: January 27, 1980 Available at: http://www.oas.org/legal/english/docs/Vienna\%20Convention\%20Treaties.htm

${ }^{26}$ Pauwelyn J. Legal Avenues to "Multilateralising Regionalism": Beyond article XXIV. Geneva, 2007. Available at: https://www.wto.org/english/tratop_e/region_e/con_sep07_e/pauwelyn_e.pdf (accessed: 10.09.2016)

27 Vinokurov E.J., Libman A.M.. Evraziiskaia kontinental'naia integratsiia. Saint Petersburg, 2012.

28 ASEAN, CAREC, SAARC, and a number of multilateral and national development banks.

29 The CIS, the Union State of Russia and Belarus, EEU. 
In Eurasia (in addition to the global level and structure of regional free trade agreements) new formats of regional intergovernmental cooperation in the economic sphere are developing rapidly mainly due to intensifying partnership between Russia and China. Russia is strengthening economic ties through the Eurasian Economic Union (EEU) - a project of integration based on a model assuming gradual convergence in the economy (international economic relations are regulated in this international association mainly through multilateral international treaties). In 2013 China has proposed a concept for economic integration — the Silk Road Economic Belt (SREB) a transport project as well as a comprehensive economic development plan (the project is implemented by China through bilateral treaties). The EEU and the SREB are generally regarded as the main drivers for the transformation of the Eurasian space into a joint development zone ${ }^{30}$.

In May 2015, Russian President Vladimir Putin spoke of the need to link the SREB and EEU and to form a Common Economic Space spanning the entire Eurasian continent. During the International Economic Forum in St. Petersburg (June 16-17, 2016) and at the Shanghai Cooperation Organization (SCO) summit in Tashkent (June 24, 2016) and during his visit to China (June 25, 2016), Putin proposed a new vision of economic cooperation in Eurasia: a "Great Eurasian partnership" which he also referred to as "Greater Eurasia"31 (this integrated entity could include China, India, Pakistan and Iran, former Soviet states and other interested parties $^{32}$ ). The project would involve the creation of a network of bi- and multi-lateral trade agreements between the Eurasian Economic Union, China, member states of the SCO and of the Association of Southeast Asian Nations (ASEAN), as well as of the European Union. Initially, these agreements would involve the simplification and unification of regulations regarding cooperation in specific areas and in investments, as well as of technical, phytosanitary and customs regulations and regulations concerning intellectual property. Later on, the agreements would involve lowering tariffs and ultimately the creation of a free trade zone $\mathrm{e}^{33}$.

From our point of view, it is necessary to develop current multilateral international legal regulation to ensure recognition of the interests of the states affected by both Eurasian projects. The SCO could provide a potential way to link integration initiatives between Russia and China. The SCO effectively contributes to the development of trade and investment relations in Eurasia, promoting infrastructure projects and providing a platform for dialogue between business and governments.

The organization has become more multifunctional ${ }^{34}$ as it has expanded. The SCO includes Russia and China as the main initiators of the integration process. It is also important to note that the geographic area of the SCO includes all of the EEU member states. The SCO includes six member states (China, Russia, Kazakhstan, Uzbekistan, Tajikistan, and Kyrgyzstan), six observer states (Mongolia, Belarus, Iran, Afghanistan, India, and Pakistan), and six dialogue partner states (Turkey, Sri Lanka, Nepal, Cambodia, Azerbaijan, and Armenia). They are all

30 Doklad Mezhdunarodnogo diskussionnogo kluba "Valdai" "K Velikomu Okeanu 3. ekonomicheskii poias Shelkovogo putii. Prioritety sovmestnogo razvitiia evrazijskikh gosudarstv”. Moscow, 2015.

${ }^{31}$ Plenarnoe zasedanie Peterburgskogo mezhdunarodnogo ekonomicheskogo foruma. Available at: http:// kremlin.ru/events/president/news/52178 (accessed: 20.12.2016)

32 Russia eyes "Greater Eurasia”. Available at: http://www.atimes.com/article/russia-eyes-greater-eurasia/ (accessed: 20.12.2016)

33 Russia's Greater Eurasia and China's New Silk Road: Adaptation Instead of Competition Available at: https://www.osw.waw.pl/en/publikacje/osw-commentary/2016-07-21/russias-greater-eurasia-and-chinasnew-silk-road-adaptation (accessed: 20.12.2016)

34 Shilina M.G. Shanhaiskaia organizaysiia sotrudnichestva kak format politicheskogo i ekonomicheskogo vzaimodejstvii agosudarstv: reali i iperspektivy // Biznes. Obshhestvo. Vlast'. 2014, no 21, p. 41-61. 
important countries located along the path of the SREB, and they are located in six economic corridors that were delineated in the document "Vision and Actions on Jointly Building the Silk Economic Belt and 21st Century Maritime Silk Road". Thus, the SCO is well suited to play a central role as a platform for aligning the SREB and EEU.

The objectives, principles, and substance of the SREB initiative coincide with the regional economic cooperation that characterizes the SCO. The above-mentioned paper "Vision and Actions on Jointly Building the Silk Road Economic Belt and 21st-Century Maritime Silk Road" confirms this: the construction of the SREB coincides with the objectives of the SCO; both the SREB and SCO place a major emphasis on integrating infrastructure ${ }^{35}$.

Russia's Valdai Discussion Club experts also believe that "the SCO is the most important institution of international cooperation in Eurasia... and has great potential for becoming the main forum for interaction between China (the SREB) and the EEU"36.With active development, the SCO could become the central institution of the planned Greater Eurasian Community project.

\section{Conclusion}

The global and especially the Eurasian economic nexus require a legal regime that is reasonable, predictable and stable with clear, transparent and minimally restrictive laws ${ }^{37}$. Gradual economic convergence and integration of Eurasian states, in our opinion, could be based on the following mechanism of international legal regulation of economic cooperation:

- The main task is the further settlement of economic relations within the EEU. As it stands, all powers to conduct trade negotiations are ceded by member states to the Eurasian Economic Commission (at the Union level), but that is not sufficient. The absence of a common trade policy for the EEU could become a problem. Countries in the Union need to use external trade negotiations in order to improve the international competitiveness of their economies, to achieve national development goals and thereby to strengthen their national sovereignty. This can be accomplished by using a well-conceived and more flexible system of preferential trade agreements. But for this to happen it is first necessary to consider how to solve the internal problems of development, problems with expansion of EEU products into foreign markets, and how to revitalize trade policy as an integrated set of measures.

A common trade policy is an important tool, but to be effective it must move beyond mere foreign trade negotiations and toward agreements ${ }^{38}$ that will coordinate mutual investment, technical regulation and technological cooperation ${ }^{39}$. With a common trade policy, Russia and

${ }^{35}$ In the document "Declaration of the Heads of State of the Member States of the Shanghai Cooperation Organization on Building a Region of Lasting Peace and Common Prosperity", "member states attach importance to developing transport infrastructure that connects Asia with Europe, building relevant international transport corridors and improving the efficiency of multimodal transport." "The Belt and Road Initiative aims to promote the connectivity of Asian, European and African continents and their adjacent seas, establish and strengthen partnerships among the countries along the Belt and Road, and set up all-dimensional, multi-tiered and composite connectivity networks".

36 Doklad Mezhdunarodnogo diskussionnogo kluba "Valdai" ... P. 25.

37 Wood P. Law and Practice of International Finance, 2008. P. 13.

${ }^{38}$ Foreign trade agreements are changing from a simple means of trade liberalization into a major factor in economic development and an indicator of the place on the global economic stage occupied by countries and interstate associations.

39 Bordachev T. Do the EAEU Countries Need a Common Trade Policy? Available at: http://valdaiclub. com/a/highlights/do-the-eaeu-countries-need-a-common-trade-policy-/(accessed: 20.12.2016) 
its EEU partners will be able to uphold their negotiating positions with large and consolidated partners more effectively.

- In the current conditions it is important to develop trade and economic relations between the EEU and Asian countries. The next step in convergence would optimally be carried out within an EEU- China format, which would provide a framework for suitable international instruments $^{40}$ (that would bar interaction with China along bilateral lines). On this basis it is possible to establish a free trade agreement (FTA).This potential agreement between the EEU and China would not result in a substantial increase in value-added exports. However, there is general interest in opening up the markets. In addition, agreements of this kind pave the way for further talks, for example, to develop cross-border infrastructure ${ }^{41}$. An FTA between China and Russia (or the EEU) seems unlikely ${ }^{42}$, but from a long-term perspective, Russia (and the EEU) might try to entice China into concluding an FTA similar to the 2015 China-Australia Free Trade Agreement (ChAFTA). Preferential agreements with the EEU could be beneficial for countries within the union as well as for their partners.

- The next stage would include linking other states ${ }^{43}$ in the SCO (that are not members of the EEU) to this interaction. Using the SCO platform, the creation of multilateral economic agreements of the SCO should have a high priority.

The EEU and the SCO are already preparing an agreement on continental economic partnership, "a comprehensive agreement in the framework of the SCO, which presumably includes three major components: the free movement of goods, freedom of capital movement, as well as preferential access to the markets for services"44. In March 2016 Economics Ministers of China, Russia, Kazakhstan, Kyrgyzstan, and Tajikistan met in Moscow to discuss opportunities and mechanisms for transitioning to a (continental) economic partnership within the framework of the SCO. The Ministers agreed to study the feasibility of forming, over the long term, a free trade area within the Organization. The concept for such an agreement was prepared for the meeting of the SCO member state leaders held in Tashkent in June 2016. Thus, in less than a year the Russian concept of a "Greater Eurasia" grew beyond the scope of the former Soviet Union to encompass the entire Eurasian continent - and might ultimately lead to the creation of a common economic space throughout that territory ${ }^{45}$.

- A subsequent step would be coordinating economic activity between the mechanism created on the basis of the SCO and countries involved in the SREB. In addition, opportunities to conclude free trade agreements with them should be pursued.

It is also necessary to improve the tools for interaction with other megaregional partnerships. Priority should be given to working with the Regional Comprehensive Economic Partnership (RCEP) in Asia, and perhaps the Trans-Pacific Partnership (TTP) could be approached in the future.

40 «Road Map» and the Agreement on the coordination of economic cooperation.

41 Vinokurov E. EAEU and Asian Countries: Plans, Prospects and Challenges Available at: http://valdaiclub. com/a/highlights/eaeu-and-asian-countries-plans-prospects/?sphrase_id=6007 (accessed: 20.12.2016)

42 Schubert J., Savkin D. ChAFTA and the Future Prospects of a China-Russia/EAEU FTA, 2016. Available at: http://www.worldscientific.com/page/cqiss/editorial-board (accessed: 20.12.2016) Lanka.

43 Azerbaijan, Afghanistan, India, Iran, Cambodia, Mongolia, Nepal, Pakistan, Turkey, Uzbekistan, Sri

44 SCO i EEU gotoviat soglashenie o biekonomicheskom kontinental'nom partnerstve. Available at: http:// infoshos.ru/ru/?idn=15278 (accessed: 20.12.2016)

${ }^{45} \mathrm{Li}$ Xin. Chinese Perspective on the Creation of a Eurasian Economic Space. Valdai Discussion Club Report. Moscow, November 2016. Available at: http://valdaiclub.com/files/12585/ (accessed: 20.12.2016) 
At each stage, it is important to compare the international legal obligations created at the regional level to the obligations arising from any global international legal regulation and to promptly detect conflicts with WTO law.

Development of cooperation depends primarily on mutual interests and the degree of activity of the states involved in Eurasian integration.

Thus, international economic law ensures the integrity of the international economic order, and it has mechanisms to counter factors leading to fragmentation. The latest practices within state economic cooperation in Eurasia and the prospects anticipated for it require further development and implementation of proper mechanisms for its international legal regulation.

\section{I目 References}

Abdullin A.I. (2015) Fragmentatsiia mezhdunarodnogo prava: problemy i perspektivy. Aktual'nye problemy sovremennogo mezhdunarodnogo prava: materialy XII ezhegodnoi mezhd. nauchno-praktich. konferentsii pamiati prof. I.P. Blishhenko. A.H. Abashidze (ed.). Moscow: RUDN, 564 pp. (in Russian)

Bordachjov T.V. (2015) Novoe evraziistvo. Rossiia v global'noi politike, no 5. Available at: //www.globalaffairs.ru/number/Novoe-evraziistvo-17754 (accessed: 10.09.2016)

Davletgil'deev R.S. (2013) K voprosu o podkhodakh k fragmentatsii mezhdunarodnogo prava. Rossiiskii juridicheskii zhurnal, no 3. Available at: http://base.garant.ru/57741390/ (accessed: 10.09.2016)

Doklad Mezhdunarodnogo diskussionnogo kluba "Valdai" (2015) “K Velikomu Okeanu. 3 ekonomicheskii poias Shelkovogo putii. Prioritety sovmestnogo razvitia evrazijskikh gosudarstv"... Moscow, 25 pp.

Drezner D. (2009) Regime Proliferation and the Tragedy of the Global Institutional Commons. 32 pp. Available at: http: // fletcher.tufts.edu/ /media/Fletcher/Microsites/Fila/PDFs/FILA Discussion Paper No 0109.pdf (accessed: 10.09.2016)

Dupuy P. (2007) A Doctrinal Debate in the Globalization Era: On the "Fragmentation" of International Law. European Journal of Legal Studies, vol. 1, pp. 25-41. Available at: http://www.ejls.eu/1/4UK.pdf (accessed: 10.09.2016)

Gusejnov O.R. (2015) Mezhdunarodnaia ekonomicheskaia integratsiia v sfere mezhdunarodnogo prava. Evraziiskii juridicheskii zhurnal, no 1. Available at: http://weurasialaw.ru/index.php?option=com content\&view=article\&id=7080:2015-02-26-09-22-04\&catid=109:2010-06-17-09-48-32 (accessed: 10.09.2016)

Hafner G. (2000) Riski fragmentatsii mezhdunarodnogo prava // Ezhegodnik Komissii mezhdunarodnogo prava, vol. II, $369 \mathrm{pp}$.

Lavranos N. (2009). The Brazilian Tyres Case: Trade Supersedes Health. Trade, Law and Development, vol. 1, no 2, pp. 191-230.

Leben C. (2010) The Advancement of International Law. Oxford: Hart Publishing, 339 pp.

Lomakin V.K. (2007) Mirovaia ekonomika. Uchebnik [The Global Economics. Textbook]. Moscow: Unity-Dana, 672 pp. (in Russian)

Pauwelyn J. (2004) Bridging Fragmentation and Unity: International Law as a Universe of Inter-Connected Islands, Michigan Journal of International Law, no 25, pp. 905-915.

Pauwelyn J. (2007) Legal Avenues to "Multilateralizing Regionalism": Beyond Article XX (2012). Geneva, 35 pp. Available at: https://www.wto.org/english/tratop_e/region_e/con_sep07_e/pauwelyn_e.pdf (accessed: 10.09.2016).

Platsas A. (2012) The Idea of Legal Convergence and Electronic Law. Values and Freedoms in Modern Information Law \& Ethics, pp. 679-688.

Plotnikov A.V. (2013) Evolutsiia doktrinal'nykh podhodov k ponimaniju i otsenke fragmentatsii mezhdunarodnogo prava. Rossiiskii juridicheskii zhurnal, no 3, pp.15-19.

Slaughter A.M. (2004) A New World Order. Oxford: University Press, 341 pp.

Smbatjan A.S. (2011) WTO i regional'nye integratsionnye ob"edineniia: so otnoshenie "pravovykh sil" v uregulirovanii torgovykh sporov. Rossiiskii vneshnii ekonomicheskii vestnik, 8th edition.

Vinokurov E.J., Libman A.M. (2012) Evraziiskaia kontinental'naia integratsiia. [Euroasian Economic Integration]. Saint Petersburg: Vesti, 224 pp. (in Russian) 